\title{
The Portuguese Agrifood Traditional Products: main constraints and challenges ${ }^{1}$
}

\author{
Isabel Rodrigo ${ }^{2}$, Artur Cristóvão ${ }^{3}$, Manuel Luís Tibério ${ }^{4}$, \\ Alberto Baptista ${ }^{5}$, Lara Maggione ${ }^{6}$ and Miguel Pires ${ }^{7}$
}

\begin{abstract}
Although Portugal registers a large number of protected brand names, its economic turnover is very low when compared to the other southern EUMember States. To identify and analyze the main reasons of this weak economic significance of the Portuguese quality traditional agrifood products are the main goals of this paper. The main conclusions from the data gathered in step one of the research, which main goal was to understand the main reasons why agricultural firms do not adhere to the PDO/PGI food systems, are related with several issues, namely: the economic and transactions costs of certification, the heavy bureaucracy related to the certification process, the small difference in prices between PDO/PGI products and standard products, within the same reference market, and the preferences of Portuguese consumers. According to the respondents, Portuguese consumers do not know nor socially valorize PDO/PGI products, and privilege (i) traditional/local standard products, instead of PDO/
\end{abstract}

1. Study developed under the Rural Natework Project "Observatório de sistemas de produção localizados e valorização de produtos locais; Identificação, análise e divulgação de boas práticas de comercialização e valorização de produtos agro-alimentares tradicionais" (PNRR: PA 0400157-58-59).

2. Professora Associada com Agregação, Departamento de Ciências e Engenharia de Biossistemas (DCEB) do Instituto Superior de Agronomia da Universidade de Lisboa (ISA-ULisboa) e investigadora do Instituto de Ciências Agrárias e Ambientais Mediterrâneas (ICAAM). E-mail: isarodrigo@isa.ulisboa.pt

3. Professor Catedrático do Departamento de Economia, Sociologia e Gestão da UTAD e investigador do Centro de Estudos Transdisciplinares para o Desenvolvimento, Vila Real, Portugal. E-mail: acristov@utad.pt

4. Professor Auxiliar do Departamento de Economia, Sociologia e Gestão da UTAD e investigador do Centro de Estudos Transdisciplinares para o Desenvolvimento, Vila Real, Portugal. E-mail: mtiberio@utad.pt

5. Investigador Auxiliar do Departamento de Economia, Sociologia e Gestão da UTAD e do Centro de Estudos Transdisciplinares para o Desenvolvimento, Vila Real, Portugal. E-mail: abaptist@utad.pt

6. Estudante do Mestrado em Viticultura e Enologia, Departamento de Ciências e Engenharia de Biossistemas (DCEB) do Instituto Superior de Agronomia da Universidade de Lisboa (ISAULisboa). E-mail: laraenge@gmail.com

7. Mestrado em Ciências Económicas e Empresariais e Assistente de Investigação no Centro de Estudos Transdisciplinares para o Desenvolvimento, Vila Real, Portugal. E-mail: miguelpires@utad.pt 
PGI products, and (ii) proximity marketed relationships. These latter findings contribute to highlight, not only why the interviewed firms do not adhere to the PDO/PGI systems, but also why the Portuguese PDO/PGI domestic market is narrow when compared with the ones of southern EU-Member States.

Key-words: Traditional agrifood products, qualified products, PDO/PGI products.

JEL Classification: Q180.

DOI: http://dx.doi.org/10.1590/1234-56781806-94790053s01002

\section{Introduction}

The EU agricultural product quality policy, introduced in 1992 by the Geographical Indications (GI) scheme and presently governed by the Council Regulation (EC) 1151/2012 on the promotion of Protected Geographical Indications (PGI) and Protected Designations of Origin (PDO) for agricultural products and foodstuffs, aims to highlight the quality of individual products resulting from a particular origin and/or production method. To protect names from misuse and imitation, to help consumers to understand the specific character of the products, to encourage diverse agricultural production and to improve the income of farmers and retain population in rural areas are the main goals of this policy. Bearing in mind the social an economic potential of such policy to rural development, a policy that has progressively become one of the major objectives of the Common Agriculture Policy, other European and national programs have been launched and implemented in parallel to the GI scheme. The co-financing of programs to support investment projects made by farmers and/or agricultural and processing firms involved in labeling products and related initiatives are examples of the referred programs that, along with others, aim to preserve and promote such labelled products embedded in local/rural specific natural resources, knowledge, traditions, and cultural identities and heritages.

The number and the economic significance of PDO-PGI products translate, to a large extent, the important role of such programs and policies. In 2008, the PDO-PGI European agricultural products and foodstuffs (excluding wines and spirit drinks but including beers and other beverages) had an estimated wholesale value of 14,5 million euros for 434 PDO and 330 PGI registered names ${ }^{8}$.

After the Enlargement of the European Union, and in view of the growing interest shown by producers, there has been a sudden increase of registration requests in recent years. The Commissioner for Agriculture and Rural Development considers the registration of the $1000^{\text {th }}$ designation to be an important development for quality regimes, and one that proves their enormous potential, bringing visibility onto European quality products while valuing agricultural traditions and the rural heritage (DGA, 2011). Currently the number of quality agricultural and food products under community protection is estimated to be over $1.000^{9}$ and they include (DGA, 2011): 505 Protected Designations of Origin (PDO), 465 Protected Geographic Indications (PGI) and 30 Traditional Specialties Guaranteed (TSG).

Not withstand the above scenario it is important to note that there are sharp contrasts

8. http://ec.europa.eu/agriculture/quality/schemes/index enhtm_countryfiles/EUtotal - 12.02.2013.

9. The «Piacentinu Ennese» (PDO), is an Italian sheep cheese, which became the 1000th registered designation under the Community labelling legislation for quality agricultural and food products. 
between (i) PDO/PGI products in terms of the number of brand names and its economic turnover, and (ii) EU Member States (MS) in terms of its individual contribution and involvement in the European agricultural product quality policy. The PDO/PGI sectors of beers and fruits and vegetables portray the former referred discrepancy. Taking the ranking order of each sector, concerning the number of registered brand names and its economic turnover, one concludes that each sector occupies the $10^{\text {th }}$ and $2^{\text {nd }}$, and the $2^{\text {nd }}$ and $4^{\text {th }}$ positions, respectively (Table 1 and DOOR database, country files/EU total - 13.2.2013). Concerning the discrepancies between EU-MS contribution/involvement on the GI scheme, the secondary data highlights the leading role of the southern EU-MS in terms of diversity/number of protected brand names, at the EU-27 scale (Table 1). This evidence mirrors two issues that are worth to be noted.

First of all, it shows the two EU's different geographical centers where the two main models of food governance ("re-connection" and "origin of food") are located (MARSDEN, 2001; FONTE, 2006, 2008, 2010), and, secondly, it underlines the importance of the geographical, political, socioeconomic and cultural contexts in which those models have emerged, spread and consolidated (FREIDBERG and GOLDSTEIN, 2011 , p. 24). In other words, it stresses the significance of context when one looks at the "uneven geographies of alternative food" (FREIDBERG and GOLDSTEIN, 2011, p. 25).

While the northern and central EU-MS are the early adopters of the CAP productivist model and, as such, the contexts "of longstanding exportoriented agriculture", the southern EU-MS, namely Portugal, Spain, Greece and the southern part of Italy (that together represent $61 \%$ of the total number of protected brand names, as shown in Table 1) are "the latecomers to industrial development and never fully completed their 'great transition'" (FONTE, 2008, p. 201-203). In fact, when CAP initiated its shift to support environmental farming practices, "Spain, Portugal and Greece in particular, have criticized the EU for imposing policies that [aimed] at the extensification of agriculture at the time when they [were] still mostly concerned with 'catching up' with their northern counterparts trough the intensification of commodity production" (WILSON, 2001, p. 91 in GOODMAN, 2004, p. 11, original emphasis).

On the basis of these two historical agricultural and socio political trends, while the so-called "re-connection" food governance model, that includes the organic produce and the short-

Table 1. Overview of PDO/PGI in the EU 27 (2007)

\begin{tabular}{|c|c|c|c|c|c|c|}
\hline \multicolumn{3}{|l|}{$\begin{array}{l}\text { Contribution of the main EU Member States } \\
\text { to the total number of PDO/PGI products }\end{array}$} & \multicolumn{4}{|c|}{$\begin{array}{l}\text { Contribution of the main PDO/PGI products } \\
\text { in the total number of PDO/PGI products }\end{array}$} \\
\hline France & $22 \%$ & \multirow{5}{*}{$83 \%$} & Cheeses & $25 \%$ & \multirow{3}{*}{$60 \%$} & \multirow{4}{*}{$85 \%$} \\
\hline Italy & $21 \%$ & & Fruits and vegetables & $20 \%$ & & \\
\hline Portugal & $15 \%$ & & \begin{tabular}{|l|} 
Fresh meat \\
\end{tabular} & $15 \%$ & & \\
\hline Spain & $14 \%$ & & Fresh meat and meat products & $25 \%$ & & \\
\hline Greece & $11 \%$ & & & & & \\
\hline France + Italy + Portugal + Spain + Greece + Germany & \multicolumn{2}{|c|}{$90 \%$} & & & & \\
\hline \multicolumn{3}{|c|}{$\begin{array}{l}\text { Contribution of the main EU Member States } \\
\text { to the total economic value of PDO/PGI products }\end{array}$} & \multicolumn{4}{|c|}{$\begin{array}{l}\text { PDO/PGI products according } \\
\text { to its economic significance }\end{array}$} \\
\hline Italy & $33 \%$ & \multirow{7}{*}{$94 \%$} & Cheeses & $37 \%$ & \multirow{4}{*}{\multicolumn{2}{|c|}{$83 \%$}} \\
\hline Germany & $25 \%$ & & Beers & $20 \%$ & & \\
\hline France & $17 \%$ & & Fresh meat & $22 \%$ & & \\
\hline UK & $8 \%$ & & Fruits and vegetables & $4 \%$ & & \\
\hline Spain & $6 \%$ & & & & & \\
\hline Greece & $4 \%$ & & & & & \\
\hline Austria & $1 \%$ & & & & & \\
\hline
\end{tabular}

Source: EC (2008); DGA (2010). 
food supply chains, is particularly prevailing in the northern and central EU-MS, the "origin of food" model, i.e., the quality food systems that conform to defined standards of quality regulations, is preferentially located in the above referred southern EU countries and regions. As such, while in the northern and central EU-MS the European agricultural quality policy has been a "stimulus", to a certain extent, to "re-invent local food and local knowledge" and, through this way, to "recover food cultures", in the southern EU-MS the same policy has been used mainly to "(re) valorize traditional food and local knowledge", as the Portuguese case illustrates.

In short, the GI scheme policy has played an important role not only in recovering but, essentially, in preventing the disappearance of a large and diverse amount of traditional agricultural products and foodstuffs, through their economic and social (re)valorization. Without that policy, many of such products could now be lost or, at least, would not travel out of their regional and national borders. This is valid for the referred EU southern traditional products and for the Portuguese ones in particular. In fact, out of the five EU southern countries, Portugal occupied, in 2008, the leading position concerning the economic value of PDO-GPI in the Intra and in the Extra-EU trade, with $36 \%$ and $13 \%$, of the total economic value, respectively. The corresponding values for Greece, Spain, Italy and France were, respectively, 26\% and 6\%; $10 \%$ and $4 \% ; 13 \%$ and $8 \%$, and $7 \%$ and $1 \%$ (DOOR database, country files - 13.2.2013).

\section{Study of the Portuguese Case}

Although Portugal registers a large number of protected brand names ${ }^{10}$, its economic turnover is very low when compared to the other southern EU-MS (see Table 1). In 2007, this

10. In 2009, Portugal had 121 brand names registered: 59 PDO; 59 PGI and 3 Traditional Speciality Guaranteed (TSG) (GPP, 2012, p. 5). economic turnover was around 70 million euro, representing only $0.5 \%$ of the EU-27 estimated wholesale value of PDO/PGI agricultural products (GPP, 2010). To identify and analyze the main reasons of this weak economic significance of Portuguese quality traditional agrifood products, in spite of the large number and diversity of PDO/PGI products and sectors, are the main goals of this paper.

Despite the great diversity of published research in the field of Portuguese quality traditional agrifood products ${ }^{11}$, it is important to have the overall picture and assessment about the main constraints and challenges currently faced by the different actors involved either in PDO/ PGI products of each sector, in their reference markets ${ }^{12}$, and in corresponding standard products ${ }^{13}$, accordingly to their own perspectives. In parallel, the research aims to assess other issues, namely the resilience of local agrifood production systems and their contribution to rural development.

The fieldwork, still in progress, is based on face-to-face interviews of stakeholders located in the two Portuguese regions with the greatest number of Portuguese quality traditional agricultural products and foodstuffs: the North and the Alentejo. The PDO/PGI sectors selected in Alentejo, more precisely in the NUTS III Alentejo Central, Baixo Alentejo and Alto Alentejo, were fresh meet (beef, sheep and pork), processed meat (sausage products), olive oil, cheeses and fruits. The selected products in the Northern region, more precisely in NUTS III Alto Trás-os-Montes, Douro, Cávado e Grande Porto, were fresh meet, processed meat (sausage products), olives and

11. For a comprehensive list of the different topics of this published research, see Tibério and Diniz (2012).

12. A product's reference market is defined by the product itself and its closest by-products (TIBÉRIO and CRISTÓVÃO, 2004, p. 163). In the context of the present paper, the reference market of a PDO/PGI product in the market defined by the standard product sector in which the PDO/PGI product is integrated.

13. Non-certified product of the same reference sector or transacted without certification. 
olive oil, cheeses, horticultural products, fruits (almond, apple and chestnut) and honey. The referred sectors were selected on the basis of their representativeness in each region, according to the secondary information sources published in the most recent annual reports issued by the Ministry of Agriculture Planning and Policies Department (GPP, 2010, 2012).

The selection of stakeholders to be interviewed was based on the agricultural product quality investments that, in each region, have been co-financed by European and/or national policies and programs, namely the Agriculture and Rural Development Operational Program ("Programa Operacional de Agricultura e Desenvolvimento Rural", AGRO) $)^{14}$ and the so called "Medida AGRIS"15 from the III Communitarian Support Framework, both in force during 2000-2006, and the Rural Development Program ("Programa de Desenvolvimento Rural"), currently being implemented (2007-2013) ${ }^{16}$.

The research/fieldwork was organized in two steps. In the first one, 10 (medium and large) firms producing standard products were selected in each region. The goal of the interviews was to analyze the main reasons why managers of those firms were not involved, nor interested in the certification of the total, or at least, the major part of the production. The interviews, mostly gathering qualitative data, focused on the following indicators: links of the firms to the local/rural territory in terms of the raw materials processed and their producers, firm's infrastructures and processing technologies,

14. More precisely, Measure 2 oriented to support "Processing and marketing of agricultural products".

15. More precisely, the Action 2 clearly focused on the "Development of Agricultural Products Quality", trough Measure 2.1 (Creation and modernization of production units, "Criação e modernização de unidades produtivas") and 2.2 (Incentives to quality products, "Incentivos a produtos de qualidade").

16. More precisely, the Measure 1.1.1 (Modernização e Capacitação das Empresas) of action 1.1. (Inovação e Desenvolvimento Empresarial) of the sub-program 1 (Competitividade). number of products and by-products processed and commercialized, production volume and generated turnover, main destinations markets (national, regional or local and international), research and development activities and a SWOT analysis.

In the second step of the research, still in process, interviews are being held, in each region, with PDO/PGI producers associations and certification bodies, e.g., entities which are responsible for managing and certifying the designations. In addition, for each one of the reference sectors under scrutinity in each region, firms that process and commercialize (i) PDO/ PGI products and (ii) standard products will be also interviewed. The main goals of the second step of the research is to understand how the various actors/stakeholders involved at the local level (agricultural firms, processing firms, certification bodies and producers associations) take part in the process leading to the application for and functioning of PDO/PGI, which are their main advantages/disadvantages and their main expected benefits and constraints, which factors are responsible for the low economic significance of PDO/PGI products, and, indirectly, which are the consequences of the current PDO/PGI food systems for rural development.

The interview questionnaires to be applied to producers associations and certification bodies include the following quantitative and qualitative indicators: number and types of the managed PDO/PGI, their functioning markets, constraints and challenges, the social and economic importance of certification, and opinion about the european agricultural product quality policy. Concerning the firms processing and commercializing PDO/PGI products and standard products, interviews will gather information about PDO/PGI production and marketing, detailed functioning and "best practices", social and economic importance of certification, opinion about the European agricultural product quality policy and SWOT analysis. 


\section{Major results}

\subsection{Why medium and large agrifood firms have little interest in the PDO/PGI?}

This section reflects the data collected in the northern region of Portugal. Of the 10 firms studied in the first fieldwork step (standard products), 2 are cooperatives and the remaining 8 are societies. Together they work with a variety of agricultural products and foodstuffs, but each ones is specialized in a specific production: milk and cheese; fresh meet; sausages; horticultural products; fresh and processed fruits (including chestnut); and olives and olive oil. The following table presents an overview of these firms, according to the major studied indicators.

The next table shows the results of the SWOT analysis of the 10 cases, being worth to underline, on the positive side, the technological modernization, and, on the negative one, the low levels of production and weak management skills and involvement in networks.

The main conclusions from the data gathered in step one of the research, which principal goal was to understand the main reasons why

Table 2. An Overview of the 10 Firms

\begin{tabular}{ll}
\hline \multicolumn{1}{c}{ Indicators } & \multicolumn{1}{c}{ Main Features } \\
\hline History and recent investments & $\begin{array}{l}\text { Longstanding activity; mainly family business; investments in facilities and te- } \\
\text { chnological modernization }\end{array}$ \\
\hline Facilities and technology & $\begin{array}{l}\text { Improved facilities; modern technologies; implementation of food security pro- } \\
\text { cedures (HACCP) }\end{array}$ \\
\hline Raw materials & $\begin{array}{l}\text { Mostly national; lack of national fruits for industrial purposes (the national ma- } \\
\text { rket does not guarantee quality, price stability and the compliance with con- } \\
\text { tracts); linkages with producers; weak power control of suppliers }\end{array}$ \\
\hline Quality control and certification & $\begin{array}{l}\text { Implementation of legal requirements; mostly internal control; seven cases of } \\
\text { external certification (ISO 9001, ISO 22000, Global GAP, BRC) }\end{array}$ \\
\hline Linkages with knowledge and innovation cen- & $\begin{array}{l}\text { Usually weak, with three exceptions (two firms operating in the area of proces- } \\
\text { sed fruits for dairy, ice cream, bakery and juice industries have budgets for rese- } \\
\text { arch and one created a research \& development unit; a cheese industry works } \\
\text { closely with university researchers) }\end{array}$ \\
\hline Markets & $\begin{array}{l}\text { Proximity of clients and suppliers; mostly national markets in the case of meet, } \\
\text { sausages, cheese, honey and fresh fruits; mostly international markets in the } \\
\text { case of processed fruits and chestnuts; diversity of market approaches (direct } \\
\text { selling, retailers, supermarket chains); promotion in regional and national fairs; } \\
\text { scarce budget for market research and communication/promotion }\end{array}$ \\
\hline Differentiation and qualification (PDO/PGI) & $\begin{array}{l}\text { Only 2 out of 10 firms produce and sell PDO/PGI products (meet and olive oil; in } \\
\text { the case of olive oil, only about 4\% of the production is certified as DOP) }\end{array}$ \\
\hline Future challenges and prospects & $\begin{array}{l}\text { Diversification; increased market share; new markets; internationalization; in- } \\
\text { novation; sustainability (byproduct recycling, environment-friendly practices); } \\
\text { social responsibility }\end{array}$ \\
\hline
\end{tabular}

Source: Authors' elaboration.

Table 3. SWOT Analysis of the 10 Firms

\begin{tabular}{|c|c|}
\hline Strengths & Weaknesses \\
\hline $\begin{array}{l}\text { - Production capacity } \\
\text { - Flexibility and response to market (tailor-made solutions) } \\
\text { - Technical expertise } \\
\text { - Progresses in human resource development }\end{array}$ & $\begin{array}{l}\text { - High production costs } \\
\text { - High capital costs } \\
\text { - Production level below capacity } \\
\text { - Weak management skills } \\
\text { - Weak involvement in networks (innovation, markets, lobbying) }\end{array}$ \\
\hline Opportunities & Threats \\
\hline $\begin{array}{l}\text { - Market demand for differentiation } \\
\text { - Growing international demand } \\
\text { - Linkages and networking with knowledge and innova- } \\
\text { tion centers }\end{array}$ & $\begin{array}{l}\text { - Economic crisis } \\
\text { - Political instability } \\
\text { - Competition from lower-quality products }\end{array}$ \\
\hline
\end{tabular}

Source: Authors' elaboration. 
agricultural and agrifood firms do not adhere to the PDO/PGI food systems are related with several issues, namely:

- The lack of raw material, particularly in the case of fruits for industrial processing;

- The limited opportunities for innovation resulting from the product specification forms (especially mentioned by a cheese industry);

- The economic and transactions costs of certification;

- The heavy burocracy related to the certification process;

- The small difference in prices between PDO/PGI products and standard products (within the same reference market); and

- The Portuguese consumer's food preferences.

According to the respondents, Portuguese consumers do not know nor socially valorize PDO/PGI products, and privilege (i) traditional/ local standard products, instead of PDO/ PGI products, and (ii) proximity market relationships. These latter findings contribute to highlight not only why the interviewed firms do not adhere to the PDO/PGI systems, but also why the Portuguese PDO/PGI domestic market is so narrow when compared with the ones of southern EU-MS.

\subsection{What is the importance of PDO/PGI?}

The second steps of the study, as explained before, is still in progress and involves PDO/PGI producers associations and certification bodies, along with firms that process and commercialize (i) PDO/PGI products and (ii) standard products. The northern region of Portugal, focus of this paper, has a total number of $41 \mathrm{PDO} / \mathrm{PGI}$ products, about $35 \%$ of the total of 118 existing in Portugal. However, in 2009 only 16 were actually present in the market (about $40 \%$ ).

The already interviewed agents are producers associations that serve as management entities (11) and one private certification body, and reflect a variety of product chains, namely fresh meet (beef, sheep, goat and pork), processed meat (sausage products), olives and olive oil, cheese, honey, horticultural products and fruits (almond, apple and chestnut). The following table presents an overview of the positive and negative aspects related to the concerned PDO/PGI, as perceived by these respondents. The fieldwork still in progress will permit to complete this picture, representing the view of about 50 agents involved in PDO/PGI product chains.

The interviewed agents also pointed out a number of obstacles and future prospects and challenges that are worth to mention:

- Obstacles: poor chain organization; many producers/processors don't need the PDO/ PGI to ensure the quality of their products; large retailers protect their own brands; most consumers don't know the attributes of PDO/PGI products; many product specifications are not adequate and need reformulation; certification costs are high; and the number of PDO/PGI producers is small and tends to decrease;

Table 4. PDO/PGI: Positive and Negative Aspects

\begin{tabular}{l|l|l}
\hline \multicolumn{1}{c|}{ Dimension } & \multicolumn{1}{|c}{ Positive Aspects } & \multicolumn{1}{c}{ Negative Aspects } \\
\hline $\begin{array}{l}\text { Creation of } \\
\text { PDO/PGI }\end{array}$ & $\begin{array}{l}\text { - Product specification } \\
\text { - Adding value to the product } \\
\text { - Effort of chain organization }\end{array}$ & $\begin{array}{l}\text { - "Top-down" approaches dominated the initial stages } \\
\text { - Product specification does not reflect some characteristics (too general) } \\
\text { - Update of product specification is too slow } \\
\text { - Inadequate choice of management body, with negative impacts in the } \\
\text { process (almond, chestnut, honey) } \\
\text { - Small number of PDO/PGI per management body }\end{array}$ \\
\hline $\begin{array}{l}\text { Type of } \\
\text { qualification }\end{array}$ & - PGI is more flexible & $\begin{array}{l}\text { - Many agents give more value to own commercial brand } \\
\text { - Some products are PDO and should be PGI, and vice versa } \\
\text { Poor definition of geographical areas, with exclusion of territories (olive } \\
\text { oil, apple) }\end{array}$ \\
\hline
\end{tabular}




\begin{tabular}{|c|c|c|}
\hline Dimension & Positive Aspects & Negative Aspects \\
\hline $\begin{array}{l}\text { Farmers and } \\
\text { processors }\end{array}$ & $\begin{array}{l}\text { - Economic return } \\
\text { - Uniform production rules } \\
\text { - Preservation of species and varieties/ } \\
\text { breeds (biodiversity) }\end{array}$ & $\begin{array}{l}\text { - Update of product specification is too slow } \\
\text { - Lack of commitment } \\
\text { - Abusive use of the qualified name by industries }\end{array}$ \\
\hline Differentiation & $\begin{array}{l}\text { - Promotion initiatives } \\
\text { - Differentiation in terms of design, } \\
\text { packaging and distribution channels }\end{array}$ & $\begin{array}{l}\text { - It is difficult to differentiate some products (cases of apple, chestnut } \\
\text { and olives) } \\
\text { - Some traditional varieties/breeds are close to extinct and have been } \\
\text { replaced by imported ones } \\
\text { - Certification market is small, with implication for the sustainability of } \\
\text { the private certification bodies }\end{array}$ \\
\hline $\begin{array}{l}\text { Markets and } \\
\text { consumers }\end{array}$ & $\begin{array}{l}\text { - Quality is recognized by niche } \\
\text { markets } \\
\text { - Consumer demand has been growing } \\
\text { - Large supermarkets have shown } \\
\text { interest }\end{array}$ & $\begin{array}{l}\text { - Market has poor knowledge of the attributes of the product } \\
\text { - It is difficult to differentiate some products } \\
\text { - It's hard to fight the abuse of the qualified name } \\
\text { - Lack of control over the chain } \\
\text { - Most consumers don't know the attributes of PDO/PGI products } \\
\text { - Distribution in general is not compromised with qualification } \\
\end{array}$ \\
\hline $\begin{array}{l}\text { Role of public } \\
\text { services }\end{array}$ & $\begin{array}{l}\text { - Political and technical leadership in } \\
\text { the initial stages of the qualification } \\
\text { process } \\
\text { - Some thematic promotion initiatives }\end{array}$ & $\begin{array}{l}\text { - Heavy bureaucracy } \\
\text { - National authorities are presently too passive } \\
\text { - Lack of advisory work } \\
\text { - Lack of information to consumers }\end{array}$ \\
\hline $\begin{array}{l}\text { Role of } \\
\text { European } \\
\text { policy }\end{array}$ & $\begin{array}{l}\text { - Quality policies of the CAP are rele- } \\
\text { vant and necessary }\end{array}$ & $\begin{array}{l}\text { - Too much importance given to the economic dimension and less to } \\
\text { the cultural one } \\
\text { - Heavy bureaucracy } \\
\text { - Lack of promotion initiatives }\end{array}$ \\
\hline $\begin{array}{l}\text { Value of } \\
\text { qualification }\end{array}$ & $\begin{array}{l}\text { - Product differentiation } \\
\text { - Economic return (farmers) } \\
\text { - Observance of rules and regulations } \\
\text { by processors }\end{array}$ & $\begin{array}{l}\text { - Quality is only recognized by restrict niche markets } \\
\text { - Lack of knowledge of consumers } \\
\text { - Distribution agents are not committed to the process of qualification }\end{array}$ \\
\hline
\end{tabular}

Source: Authors' elaboration.

- Future prospects and challenges: to professionalize the PDO/PGI management structures; to involve the chain actors more actively; to join efforts and gain scale in the areas of processing and distribution; to increase the scale of PDO/PGI through merger processes (for instance, to merge the three northern chestnut PDO in a single one) or through other organization mechanisms permitting economies of scale.

\section{Conclusions}

There are already over a thousand agrifood products with a protected designation (PDO/ PGI/TSG) according to the European agricultural product quality policy. About 800 of these products are regularly available in the market and generated over 14 billion Euro worth of business volume. Portugal represents around $15 \%$ of those products (118), but only $0.5 \%$ (70 million Euros) of the overall volume of business. These indicators clearly show that most Portuguese PDO/PGI products are small scale, have a weak presence in the market and a low economic value. As a matter of fact, they are worth only $0.56 \%$ of the volume of business generated by the national agrifood industry.

Portuguese qualified products are distributed according to the following designations: PDO $(48 \%)$, PGI $(49.5 \%)$ TSG $(2.5 \%)$. The sectors of traditional sausage $(31 \%)$, fresh meat $(24 \%)$, fruits $(18 \%)$ and cheeses $(12 \%)$ are the most representative in number of products. As regards volume of business, the most important sectors are: fruits $(45 \%)$, cheese $(19 \%)$, fresh meat $(17 \%)$ and olive oil (15\%).

In general terms, PDO/PGI production in Portugal has been increasing gradually, but its market share is still low in the context of its reference markets. Tibério (2004) points out some factors which may account for this situation, such as: (i) the diversity of resources, and the dynamics 
and capacities of the PDO/PGI managing entities to differentiate and to commercialize the product; (ii) the "top-down" generation of some processes of PDO/PGI registration and management; (iii) the nature of each product and its productive and commercial dimension; and (iv) the sustainability of the traditional channels in the retail trade.

Northern Portugal, particular the interior areas of Alto Trás-os-Montes and Douro, has a total number of $41 \mathrm{PDO} / \mathrm{PGI}$ products, about 35\% of the total of 118 existing in Portugal. However, in 2009 only 16 were actually present in the market (about 40\%). The research presented in this paper shows that medium and large agrifood firms show a small interested in PDO/ PGI. In fact, only 2 out of 10 studied firms produce and sell PDO/PGI products, meet and olive oil, but in the case of olive oil only about $4 \%$ of the production is certified as DOP. Six major obstacles were underlined by the respondents, namely: the lack of raw material, particularly in the case of fruits for industrial processing; the limited opportunities for innovation resulting from the product specification forms (especially mentioned by a cheese industry); the economic and transactions costs of certification; the heavy bureaucracy related to the certification process; the small difference in prices between PDO/PGI products and standard products (within the same reference market); and the Portuguese consumers food preferences, more oriented to traditional/ local standard products, instead of PDO/PGI products, and to proximity market relationships.

The interviewed leaders of producers associations that serve as management entities and the main private certification body operating in the region presented a broad set of positive and negative aspects associated with the implementation and importance of PDO/ PGI products. If it is true that these products created, in some sectors (fresh meet, sausages), an economic dynamic, adding value to some traditional agricultural products and foodstuffs and contributing to the preservation of cultural traditions and biodiversity, it is also a fact that the implementation processes were affected by poor chain organization and decision making, a scale that tends to be rather small, quality recognition by restrict niche markets, lack of knowledge on the part of consumers, and distribution agents loosely or not committed to the qualification.

In this scenario, the main goals of the policy, namely to encourage diverse agricultural production, to improve the income of farmers and to retain population in rural areas, are undermined. Portugal is among the "the latecomers to industrial development" that "never fully completed their 'great transition'" to modernized and intensive farming (FONTE, 2008, p. 201-203), and that is particularly the case of the studied region, and especially Alto Trás-os-Montes and Douro, in the interior part of Portugal's mainland. The "origin of food" model embraced by the State and producers' organizations, having in mind to "(re)valorize traditional food and local knowledge". However, there is an array of challenges which need to be considered, in the fields of organization, actor participation, production scale, market approach and consumer behavior.

\section{References}

DGA. Registado 1000.. Produto de Qualidade, IP/11/154, Bruxelas, 15 de Fevereiro de 2011 (http:// ec.europa.eu/agriculture/).

FONTE, M. Slow food's presidia: What small producers do with big retailers? In: MARSDEN, T. e MURDOCK, J. (Ed.). Between the Local and the Global: Confronting Complexity in the Contemporary Agri-food System. London: Elsevier, 2006, p. 203-240.

Knowledge, food and place: a way of producing, a way of knowing. Sociologia Ruralis, v. 48, n. 3, p. 200-222, 2008.

. Food Relocalisation and Knowledge Dynamics for Sustainable Rural Areas. In: FONTE, M. e PAPADOPOULOS. Naming Food After Places: Food Relocalisation and Knowledge Dynamics for Rural Development. Farnham, UK: Ashgate, 2010, p. 1-35.

FREIDBERG, S. and GOLDSTEIN, L. Alternative food in the global south: reflections on a direct marketing initiative in Kenya. Journal of Rural Studies, v. 27, p. 24-34, 2012. 
GOODMAN, D. Rural Europe redux? Reflections on alternative agro-food networks and paradigm change. Sociologia Ruralis, v. 44, n. 1, p. 3-16, 2004.

GPP. Inquérito aos Agrupamentos Gestores de Produtos com Nomes Protegidos DOP/IGP/ETG - 2006-2007, Ministério da Agricultura, Mar, Ambiente e Ordenamento do Território, 2010.

$$
\text { Inquérito aos Agrupamentos Gestores de }
$$

Produtos com Nomes Protegidos DOP/IGP/ETG - 20082009, Ministério da Agricultura, Mar, Ambiente e Ordenamento do Território, 2012.

MARSDEN, T. New Communities of Interest in Rural Development and Agro-food Studies. An Exploration of Some Key Concepts, Paper presented at the Workshop "Rethinking food production-consumption: Integrative perspectives on agrarian restructuring, agro-food networks and food policies, University of California, Santa Cruz, nov./dec. 2001.

TIBÉRIO, M. L. Construção da qualidade e valorização dos produtos agro-alimentares tradicionais - Estudo da região de Trás-os-Montes. Ph. D. Thesis, Universidade de Trás-os-Montes e Alto Douro, Vila Real, 2004, 541p.

. and CRISTÓVÃO, A. Tipicidade, especificidade e definição da qualidade dos produtos agro-alimentares tradicionais. O caso dos produtos DOP/IGP de Trás-osMontes. In: II Congresso de Estudos Rurais: Periferias e Espaços Rurais, SPER, Universidade dos Açores, Angra do Heroísmo, set. 2004.

. and DINIZ, F. Agrifood traditional products: from certification to the markets - Portuguese recent evolution. Regional Science Inquiry Journal, v. IV, n. 2, p. 57-86, 2012. 